a structure during an earthquake so that their records would help in the interpretation of the results of experiments made on models attached to 'shaking tables'.

Mr. Thornton gave much detailed information about the nature and causes of the destruction which occurred in the earthquakes at Quetta, Anatolia, Antiqua and elsewhere, and discussed the effects produced on different buildings. The immediate consequences on foundations depend on the elastic properties of the subsoil, and the wide range of the values of these was shown in a table giving the velocity of compressional waves in typical strata. The effects of faulty distribution of loading were pointed out, the danger of heavy roofs, the general advantage of light rather than heavy construction, and the need for good material and workmanship and strictly appropriate design. In conclusion, he emphasized the need for more information regarding earthquakes, and suggested the collaboration of seismologists and engineers in examining the problems by means of records taken by instruments suitably designed for the purposes of both.

\section{THE TRANS-CANADIAN HIGHWAY}

$\mathrm{T}$ HE last western link in the Trans-Canadian highway-the Big Bend section in the Revylstoke district of British Columbia-was opened officially by the Premier of British Columbia, Mr. T. D. Patullo, a fow weeks ago. The road provides motorists for the first time with an all-Canadian direct route from the prairies to the Pacific coast. The ceremony took place at Baat Encampment, where David Thompson first saw the Columbia River and began its exploration in 1906.

Roads and Road Construction of September 22 states that the completion of a Trans-Canadian highway, long the dream of Canadians, who have to motor through the United States to get to Manitoba from Ontario, may await the end of the War, although only a small stretch now remains uncompleted. Two highways are proposed in north. western Ontario, either of which would, when completed, constitute the final link between British Columbia and Nova Scotia, but according to a statement made by Mr. R. M. Smith, Ontario Deputy Highways Minister, "it depends on the War when we can get back to heavy work on the projects". He added that War-time economics have eut down capital expenditures to almost nothing and stated that the date on which work can be resumed is indefinite.

The route most likely to be completed first is the far northern one, on which about two hundred prisoners housed in road camps are at present working between Long Lac and Hearst. The work involves about 135 miles, and from about a million to $1 \frac{1}{5}$ million pounds will be necessary for the completion of the work after the prisoners have cleared the land and undertaken preparatory work.

The other route, on which constructional work was suspended in 1936, lies between Schreiber, on the north shore of Lake Superior, east to White River, and south-east to the Montreal River, in the Timiskaming district, a distance of approximately 250 miles. The Deputy Minister estimated that completion of the work will cost between five and six million pounds.

\section{APPOINTMENTS VACANT}

APPLICATIONS are invited for the following appointments on or before the dates mentioned

GradUate IN ENGINERRING at the Ipswich School of Engineering The Secretary for Education, Tower House, Ipswich (October 2). Lecturer in Mechanical Engineering-The Clerk to the Governors, Derby Technical College, Normanton Road, Derby (October 5)

RESLENT TUTOR-The Secretary, Bedford College for Women, Regent's Park, N.W.1 (October 5).

TEACHER OF ENGINEERING SUBJECTs-The Principal, County Technical College, Gainsborough, Lines.

Doyestio Scienoe Mistress, and a Science Mistress (Botany AND BroLOGY), for a Boarding School in Cape Province, South Africa -The Education Section, Society for Overseas Settlement of British Women, 16 Northumberland Avenue, W.C.2.

\section{REPORTS AND OTHER PUBLICATIONS}

(not included in the monthly Books Supplement)

\section{Great Britain and Ireland}

Scientific Proceedings of the Royal Dublin Society. Vol. 22, (N.S.), No. 31: Salmon of the Ballisodare River. 1: History of the Ballisodare Fishery. By Arthur E. J. Went. Pp. 289-306+plate 7. 28. 6d. Vol. 22, (N.S.), No. 32 : Soil and Fresh-Water Iodine-Content in Ireland in relation to Jndemic Goitre Incidence. By James C. Shee. Pp. 307-314. 18. (Dublin : Hodges, Figgis and Co., Ltd. ; London :

New Leadership. By Garth Lean and Morris Martin. Pp. 22 London: William Heinemann, Ltd.) 3d. [109 King's College : Dove Marine Laboratory Report for the Year ending July 31st, 1939. (Third Series, No. 7.) Pp. 32. (Cullercoats Dove Marine Laboratory.)

Eire: Roinn Talmhaidheachta (Department of Agriculture) Brainse Iascaigh (Fisheries Branch). Report on the Sea and Inland Fisheries for the Year 1938. (P. No. 4055.) Pp. 36. (Dublin : Stationery Tyneside: the Social Facts. By Dr. David M. Goodfellow. Pp.
80. (Newcastle-upon-Tyne: Co-operative Printing Society, Ltd. 80. (Newcastle-upon-Tyne: Co-operative Printing Society, Ltd.
18. Medical Research Council. War Memorandum No. 2: Notes on the Diagnosis and Treatment of Gangrene; with a Suggested Scheme for the Bacteriological Investigation of War Wounds. Pp. ii +14. (London: H.M. Stationery Office.) $3 d$. net.

\section{Other Countries}

Denkschriften der Schweizerischen Naturforschenden Gesellschaft. Band 74, Abh. 1 : Geologie des Voirons. Par Dr. Augustin Lombard.
Pp. vi +112+5 plates. (Zürich : Gebrüder Fretz A.G.) [29

Smithsonian Institution : United States National Museum. Bulletin 175: Variations and Relationships in the Snakes of the Genus Pituophis. By Olive Grifflth Stull. Pp. vi +225 . (Washington, D.C. : phis. By Olive Griffth Stull. Pp. vi+225. (Washington, D.C.
[29

N.Z. Department of Scientiflc and Industrial Research: Christchurch Magnetic Observatory. Annual Reports for 1934, 1935, 1936. Pp. ix +132. (Christchurch: Magnetic Observatory.) 78. 6d. [39 Commonwealth of Australia: Council for Scientific and Industrial Research. Pamphlet No. 97: The Shrinkage of Australian Timbers. 2: Shrinkage Data for 170 Timbers. By W. L. Greenhill. (Division of Forest Products: Technical Paper No. 35.) Pp. 48. Pamphlet No. 98: The Prevention and Treatment of Blowfiy Strike in Sheep. Report No. 2 by the Joint Blowfly Committee. Pp. 48. (Melbourne: Ceylon. Paper 4 : Education, Science and Art (F). Administration
Report of the Acting Director of the Colombo Museum for 1939. By Report of the Acting Director of the Colombo Museum for 1939. By
P. E. P. Deraniyagala. Pp. F16. (Colombo : Government Record P. E. P. Deraniyagala. Pp. F16. (Colombo: Government Record
Office.) 15 cents. Ministério da Educacao e Saude. Anuário publicado pelo Observatório Nacional do Rio de Janeiro para o ano de 1940. (Ano 56.) Pp. xiii +460 . (Rio de Janeiro: Observatório Nacional.) [59 N.Z. Department of Scientific and Industrial Research: Apia Observatory, Apia. Annual Report for 1936 . Pp. iv +143 . 68 . Annual Report for 1937. Pp. iv +131. 68. (Wellington: Government
Printer.)

U.S. Department of the Interior : Office of Education. Bulletin 1939, No. 9: Residential Schools for Handicapped Children. By Elise H. Martens. Pp. vi +103. (Washington, D.C. : Government
Printing Office.) 15 cents. Pouth Australia : Department of Mines. Mining Review for the Half-Year ended 3ist December 1939. (No. 71.) Pp. $125+5$ plates. (Adelaide : Government Printer.) plates.

Report on the Progress of Broadcasting in India up to the 31st March 1939. Pp. xiv $+230+21$ plates. (Delhi : Manager of Publications.) 3 rupees; 58.

Ceylon. Part 4 : Education, Science and Art (G.). Administration Report of the Acting Marine Biologist for the Year 1939. By P. E. P. Deraniyagala. Pp. G9. (Colombo: Government Record (10 cent

Forest Research in India and Burma, 1938-39. Part 1: The Forest Research Institute, Dehra Dun. Pp. iii +111. (Delhi : Manager of Publications.) 2.14 rupees; 48. $9 d$. 